\title{
Why not serve an educational buffet for students? Blended learning in optics experimental education
}

Ya Zhou, Yao Hu, Liquan Dong, Ming Liu, Yuejin Zhao, et al.

Ya Zhou, Yao Hu, Liquan Dong, Ming Liu, Yuejin Zhao, Lingqin Kong, Qun Hao, Yifan Huang, "Why not serve an educational buffet for students? Blended learning in optics experimental education," Proc. SPIE 10452, 14th Conference on Education and Training in Optics and Photonics: ETOP 2017, 1045210 (16 August 2017); doi: 10.1117/12.2268864

SPIE Event: 14th Conference on Education and Training in Optics and Photonics, ETOP 2017, 2017, Hangzhou, China 


\title{
Why not serve an educational buffet for students? -- Blended Learning in Optics Experimental Education
}

\author{
Ya Zhou*, Yao Hu, Liquan Dong, Ming liu, Yuejin Zhao, Lingqin Kong, Qun Hao, Yifan Huang \\ Beijing Key Lab. for Precision Optoelectronic Measurement Instrument and Technology, \\ School of Optoelectronics, Beijing Institute of Technology, Beijing 100081, China
}

\begin{abstract}
When talking about higher education, it's hard not to run into a discussion on what's really better for student learning: online learning or traditional learning? Of course, the key is to offer both, and potentially emphasize blended learning as the less polarizing option. Online courses are much more flexible and less expensive, but powerless while hands-on practical capacity is involved. Traditional experimental course can maintain a fluid and solid learning process but is less productive due to its scheduled time and simplex access. In this paper, a buffet-style knowledge service mode applied in a 12-week-long project-based experimental course Optoelectronic Instrument Experiments (OIE) is discussed. Our purpose is to find a blended learning mode in experimental education.
\end{abstract}

Keywords: Online\&Offline Blended Learning; Project-based Course; Optics Experimental Education

\section{INTRODUCTION}

It is said that there is a new $80 / 20$ rules in college, which states that $20 \%$ of college students use $80 \%$ of resource in the university. The other $80 \%$ of students either do not make best use of their teachers and the facilities, or waste their tuition fee because they choose to skip class. There are hundreds of courses or lectures are holding simultaneously everyday in many campuses of Chinese universities. Enter into a classroom randomly, most likely you can see similar scenery: $1 / 3$ students who are usually sitting in front of the classroom are listening carefully; $1 / 3$ students are struggling and swinging between the teacher and the attraction from others stuffs; and 1/3 have surrendered to their smart phone or a nap. Moreover, I assure you, not all students who are supposed to be in that class is present. I believe none of conscientious teacher will be pleasant to see this.

What happened to our classroom education? Who should be blamed in this circumstance? The smart phone which gets even smarter every 3 months, or the student who is easily attracted by new things? Like it or not, the traditional classroom learning model is losing its power in higher education zone. What should we do? Like any exhausted mom who used all her day to prepare a healthy meal for her children while they are trying to skip the dinner for an ice cream? Should we just punish them for not finishing their vegetable? Is that an efficient way to keep them staying? Maybe. Will they begin to chew their broccoli seriously? Doubt it. Or should we cancel all traditional course and switch to online education. Let's allow our students to pursue areas of study that they find interesting. Because they are our customers, meeting or exceeding their expectations and needs should be priority.

But, how can a kid know she doesn't like green beans if she never tries green beans? Traditional learning is just like our regular meal, prosaic but nutritious. There is no reason to ditch it. A broad education provides students with knowledge that provides valuable foundation, challenges that encourage critical thinking, and experiences that build their personality. In the process, students can explore a variety of disciplines and ways of thinking, and hopefully find an area of study they wish to pursue in more depth.

Online method of education can be a highly effective alternative method of education for the students who are matured, self-disciplined and motivated, well organized and having high degree of time management skills, but it is an inappropriate learning environment for more dependent learners and has difficulty assuming responsibilities required by the online courses ${ }^{[1]}$. In addition, while hands-on practical capacity is involved, online courses are powerless. On the other hand, traditional experimental course can maintain a fluid and solid learning process but is less productive due to its scheduled time and simplex access. What if we can offer both, and potentially emphasize blended learning as the less

14th Conference on Education and Training in Optics and Photonics: ETOP 2017, edited by Xu Liu,

Xi-Cheng Zhang, Proc. of SPIE Vol. 10452, $1045210 \cdot$ (c) 2017 ICO, IEEE, OSA, SPIE

CCC code: $0277-786 \mathrm{X} / 17 / \$ 18 \cdot$ doi: $10.1117 / 12.2268864$ 
polarizing option? That is what we are trying out in the project based experimental course Optoelectronic Instrument Experiments. In this paper, we will discuss our thoughts and method in this effort.

\section{BLENDED LEARNING MODEL: LET'S SERVE A BUFFET FOR STUDENTS}

Undeniably, I really like buffets. I always eat more than I should, which makes me happy. What's amazing is that I even happy to try something I did not like when it came from my mother's kitchen. If you pay more attention, you will notice that your kids would eat more cucumbers or tomatoes in a restaurant with self-service salad bar than they eat at home. Everything looks tastier when it is put on the salad bar- that is the true beauty of dining at a buffet.

Young students usually are rebellious somehow. They would be enthusing about what they choose to do, while would be reluctant to even the same thing if they were arranged to do. One of the many reasons that some students do not like a specific course is that it is compulsory. A student might stay up later willingly just for registering the same course if he was not told that he must take this one. We already know students are more motivated by choice — what if we give them the choice to discover learning in an area that interests them?

That's what we thought: put a salad bar in our course, beside our PBL table. Let's serve a buffet for students!

\subsection{What is served in our restaurant - The project-based OIE course}

Optoelectronic Instrument Experiments (OIE) is a 12-week-long project-based experimental course which was launched at the School of Opto-Electronics, Beijing Institute of Technology in $2009^{[2]}$.OIE is a lecture-lab course which aims to familiarize students with the principal ideas of optoelectronic apparatus design and train students to apply the knowledge to identifying, analyzing and solving problems in optoelectronic system construction. The course is 12 weeks long, 4 hours per week. The course structure and contents of each week are shown in Table 1.

Table 1. Course schedule of Optoelectronic Instrument Experiments

\begin{tabular}{|c|c|c|c|}
\hline Week & Place & Content & (Learning) Objective \\
\hline $1 \sim 2$ & Classroom & $\begin{array}{ll}\text { - } & \text { Course Introduction } \\
\text { - } & \text { Principle of Optoelectronic Instrument Design } \\
\text { - } & \text { Mechanical Structure } \\
\text { - } & \text { Optoctronic Circuit Design } \\
\end{array}$ & Review \\
\hline $3 \sim 4 / 5$ & $\begin{array}{l}\text { Classroom/ } \\
\text { Lab }\end{array}$ & $\begin{array}{ll}\text { - } & \text { Optoelectronic System Analysis } \\
\text { - } & \text { Exploration of Successful Design } \\
\text { - } & \text { Grouping Student and Assigning Projects }\end{array}$ & $\begin{array}{l}\text { Give real examples of optoelectronic } \\
\text { instruments design and } \\
\text { implementation. }\end{array}$ \\
\hline $4 / 5$ & Off-class & $\begin{array}{l}\text { (Students in group) Analyzing problem to be resolved; surveying } \\
\text { information; generating alternative solutions; disassembling and } \\
\text { modularizing assignment; and dividing work among the group } \\
\text { (Teachers) Acting as consultants and advisers }\end{array}$ & \multirow{3}{*}{$\begin{array}{l}\text { That is what we called "A mini } \\
\text { simulative Cycle of Professional } \\
\text { Practice". Through this cycle, students } \\
\text { learn how to use their knowledge-to } \\
\text { focus on what they believe to be } \\
\text { important problems, identify and } \\
\text { represent a problem, analyze it, } \\
\text { generate alternative solutions, and } \\
\text { implement and assess the best } \\
\text { solution. }\end{array}$} \\
\hline $5 / 6$ & Classroom & $\begin{array}{l}\text { - (Students in group) Presenting their conception and design(including } \\
\text { project budget) in front of the whole class } \\
\text { (Teachers) Acting as a sponsors, ask question, give advice and approve } \\
\text { budget }\end{array}$ & \\
\hline$\sim 12$ & Lab & $\begin{array}{l}\text { (Students in group) constructing a functional system. The students } \\
\text { should implement their design. } \\
\text { (Teachers) Acting as supervisor and laboratory assistant, help students } \\
\text { to overcome difficulties. }\end{array}$ & \\
\hline 13 & Lab & $\begin{array}{l}\text { (Students in group) Finishing the project report, presenting their } \\
\text { achievements, and preparing for any relevant inquiry. } \\
\text { (Teachers) Acting as project-reviewer, to ask question and estimate } \\
\text { results }\end{array}$ & $\begin{array}{l}\text { Besides the professional skills, we } \\
\text { help students to improve their } \\
\text { personal and interpersonal skills. }\end{array}$ \\
\hline
\end{tabular}


After some brief general topics on optoelectronic instruments and typical introductions to several successful design examples, the students are assigned to teams and each team chooses one project to implement in ten weeks. Through the mini simulative "Cycle of Professional Practice" ${ }^{[3]}$, students will learn how to integrate the knowledge and techniques they have learned previously, and use different kinds of components and devices to construct an optoelectronic instrument. We are trying our best to impel them to be prepared for the real engineering environment they have to throw themselves into soon ${ }^{[4,5]}$.

OIE is a blended learning trial in optical experimental course which combines the traditional experimental course with projects based learning (PBL). The schedule of OIE consists of two parts: theoretical lectures and project-based experiments involving systematic analysis, design and implementation. Due to the educational resource and facilities allocation of university, the two parts are arranged in two separate periods. Theoretical lectures are centralized in the first two weeks in classroom. As other project based course, the chosen projects in OIE are usually systematical, comprehensive, and challenging. There are a lot of knowledge and skills that the students will need to accomplish their projects. Therefore, the topics and contents of the theoretical lectures are selected carefully and as condensed as possible.

In the first two weeks, we review the prerequisite topics of optical engineering briefly, including optical system design, mechanical structure, electronic circuit design and optoelectronic information processing. As we believe that imitation is the most natural way to learn, in the following two to three weeks, we analyze in depth several successful designs and instruments from our engineering research, including concept of awareness of demands, research motivation, design ideas, modular thinking and implementation. The discussed optoelectronic systems are exhibited both with photos and prototypes in the lab at the same time. Some primary methods of project management are also introduced, such as time managing, modular managing, progress managing, priority managing, paperwork managing and team managing.

\subsection{Let's put a salad bar beside the PBL table - Modularize the lectures and put them online}

OIE have been successfully carried out for nearly nine years. The procedure is a circle of trial and error, with both pleasant and pain. The experience of this course has led to insights in teaching style design, especially with respect to engineering-involved courses. It also helped us find one and another issues in the project-base course and in engineering educational pedagogy as well.

Although many initiatives have been taken by Chinese undergraduate educators to inspire students to involve themselves in real engineering environment earlier and more actively, the truth is that a few active students joined in almost all kinds of activities while most introverted students stayed in the ordinary classroom. The OIE course is compulsory and its participants are all junior students who major in Measurement \& Control Technology and Instruments. For most of them, OIE is the first project based course they ever had. According to a pre-course survey conducted among 55 students in OIE class in 2017 academic year, only 8 students have had the experience of PBL; while 19 students have never heard about it.

In the traditional teaching and assessment criterion the students are usually marked by standard answer in the examination. The participants of OIE, the junior students who were accustomed to this kind of traditional education, have no idea about what they will do in this course when they come into the OIE classroom for the first time. The term "project based course" means nothing to them even they were told so. To them OIE is just another compulsory course. They enter the classroom with their notebook, listen to the teacher carefully or occasionally, take notes when they think the contents are useful or important. By "useful or important content", it means their judgments of how the content relevant to the final exam. The topics and contents of the theoretical lectures of OIE in first two weeks, which we selected carefully and as condensed as we want, terrify or confuse them. They take either too many or too few notes, and these notes make no sense to them.

With the semester goes on, during the projects period, when they works to implement their design, some of them realize gradually what those lectures are for. BUT the window is closed, no more salad will be served. I wish there is selfservice salad bar. Yes! This is our starting point: let's put a salad bar in the dining room. 
One of the remarkable pros of online education is convenience which is in relation to study location, time, course duration, etc. Online education is easy to access and provides a convenient way to obtain course materials ${ }^{[6]}$. One can learn at his pace and study at his convenience. Learner is able to carefully reflect his/her quality thinking on each comment from others before moving on to the next topic. Although the OIE cannot switch to online model completely, if we modularize the lectures and put them online, every OIE attendee can choose the any lecture module at any time for unlimited times. They can study "Electronic Circuit Design" when they are designing the circuit board and having it manufactured, they can study "Optoelectronic Information Processing" when they have to design the algorithm and code it. Additionally, when the whole project has been implemented, they can learn how to write technical reports online as their wishes.

\subsection{What should be in our salad menu - the topics of the online lecture}

Although the online lecture model gives us much more flexibility and freedom on course design, the topics of the online lecture should also be selected circumspectly. We know the truth that too much is just as worse as too little. After careful consideration, 8 topics are selected to put online, each of them will be an independent video lecture about 30 45 minutes. The topics and their contents are shown in Table 2.

Table 2. The topics and contents of the online lecture

\begin{tabular}{|c|c|c|c|}
\hline No. & Topic & What it is about & What it is for \\
\hline 1 & $\begin{array}{l}\text { Optical system design: } \\
\text { principles; methods; and } \\
\text { examples }\end{array}$ & $\begin{array}{l}\text { Several fundamental and crucial rules and principles in optical } \\
\text { system design are discussed in this section. As examples, several } \\
\text { successful designs and instruments from real engineering } \\
\text { research are analyzed in depth. The discussed optoelectronic } \\
\text { systems are exhibited in the video. }\end{array}$ & $\begin{array}{l}\text { As we believe that imitation is the most } \\
\text { natural way to learn, real examples of } \\
\text { optoelectronic instruments design and } \\
\text { implementation will help students to } \\
\text { understand what an optical system is } \\
\text { and how it formed. }\end{array}$ \\
\hline 2 & $\begin{array}{l}\text { How to begin a real } \\
\text { engineering project design }\end{array}$ & $\begin{array}{l}\text { This section is a instruction for beginners, including concept of } \\
\text { awareness of demands, research motivation, design ideas, } \\
\text { modular thinking and implementation. Some primary methods } \\
\text { of project management are also introduced, such as time } \\
\text { managing, modular managing, progress managing, priority } \\
\text { managing and team managing. }\end{array}$ & $\begin{array}{l}\text { For most students, OIE is the first } \\
\text { project based course they ever attend. } \\
\text { This section helps students to } \\
\text { understand the meaning of projects and } \\
\text { get some basic skills to begin their own. } \\
\text { This section works as a beginner's } \\
\text { guide. }\end{array}$ \\
\hline 3 & $\begin{array}{l}\text { Technical paperwork: } \\
\text { information retrieval and } \\
\text { reports writing }\end{array}$ & $\begin{array}{l}\text { In this section, several skills and tips in information retrieval are } \\
\text { introduced, including widespread databases and their } \\
\text { distinguishing feature; basic search grammar; reading skills for } \\
\text { technical literature. Some writing skills for technical reports are } \\
\text { also discussed as well. }\end{array}$ & $\begin{array}{l}\text { Communications is considered as one } \\
\text { of the most important interpersonal } \\
\text { skills for modern engineers, which } \\
\text { include both income and outcome, oral } \\
\text { and written. We are trying to help } \\
\text { students to improve that during the } \\
\text { whole PBL. }\end{array}$ \\
\hline 4 & Electronic circuit design & $\begin{array}{l}\text { Skills and tips in electronic circuit, including princi] } \\
\text { usage of tools and instruments, and computer aide } \\
\text { software }\end{array}$ & \multirow{5}{*}{$\begin{array}{l}\text { Fundamental and essential skills in a } \\
\text { project based course. Although most of } \\
\text { this knowledge was taught theoretically } \\
\text { in the prerequisite course, how to use } \\
\text { them in real engineering environment is } \\
\text { still an obstacle for the inexperienced } \\
\text { students. These sections work as a } \\
\text { beginner's textbook. }\end{array}$} \\
\hline 5 & $\begin{array}{l}\text { Mechanical structure and } \\
\text { design }\end{array}$ & $\begin{array}{l}\text { Skills and tips in mechanical structure and design, including } \\
\text { principal ideas, usage of computer aided design software. }\end{array}$ & \\
\hline 6 & $\begin{array}{l}\text { Optoelectronic information } \\
\text { analysis and processing }\end{array}$ & $\begin{array}{l}\text { Skills and tips in optoelectronic information analysis and } \\
\text { processing, including principal ideas, algorithms and usage of } \\
\text { device. }\end{array}$ & \\
\hline 7 & Program coding skills & $\begin{array}{l}\text { Skills and tips in programming design, including program } \\
\text { architecture, computer language and Integrated Development } \\
\text { Environment(IDE) }\end{array}$ & \\
\hline 8 & $\begin{array}{l}\text { Optical design and } \\
\text { experimental skills }\end{array}$ & $\begin{array}{l}\text { Skills and tips in optical design and experiments, including } \\
\text { principal ideas, usage of computer aided design software, and } \\
\text { important rules in optical experiments. }\end{array}$ & \\
\hline
\end{tabular}

\section{WHAT WOULD STUDENTS WANT TO LEARN IF THEY CAN CHOOSE}

In the business world, customer service is a prized commodity as it directly impacts the bottom line. One way for colleges and universities to accomplish this objective is to place a renewed focus on meeting or exceeding the expectations and needs of their customers, namely their students ${ }^{[7]}$. Some suggest that we should treat students as customers and infuse customer-service principles into academia. Some would argue that higher education should focus less on the process of good customer service and more on the final product of producing educated graduates. Emery, 
Kramer and Tian (2001) said, "Students may not be excited about the hard work in the short run, but in the long run, the students will be very appreciative of the quality education that prepared them for the real world". But, should the end product of a diploma be the only concern of higher education institutions? There are a lot of discussions about this opened issue and there is no satisfying answerer yet. Finding a middle ground might be the closest answer temporarily.

The ultimate goal of OIE is to equip students with a range of important professional and personal skills. We think putting a salad bar beside our PBL table would help the students eating healthy, and we design warily the salad menu out of good intentions. But, is it what the students want? What would students want to learn if they are allowed to choose?

As an ongoing trial in blended learning model, the online lectures in our course are still under development. In this semester, a pre-course survey was conducted among all the students who signed up for the OIE course. In the survey, we listed all 8 topics which we intent to put on line. The students were asked to choose no more than 2 skills if they can equip with right away and give their reasons, or list any other skills not in the list. The popularity of the 8 topics is shown in Figure 1.

\section{Popularity of Each Independent Topic}

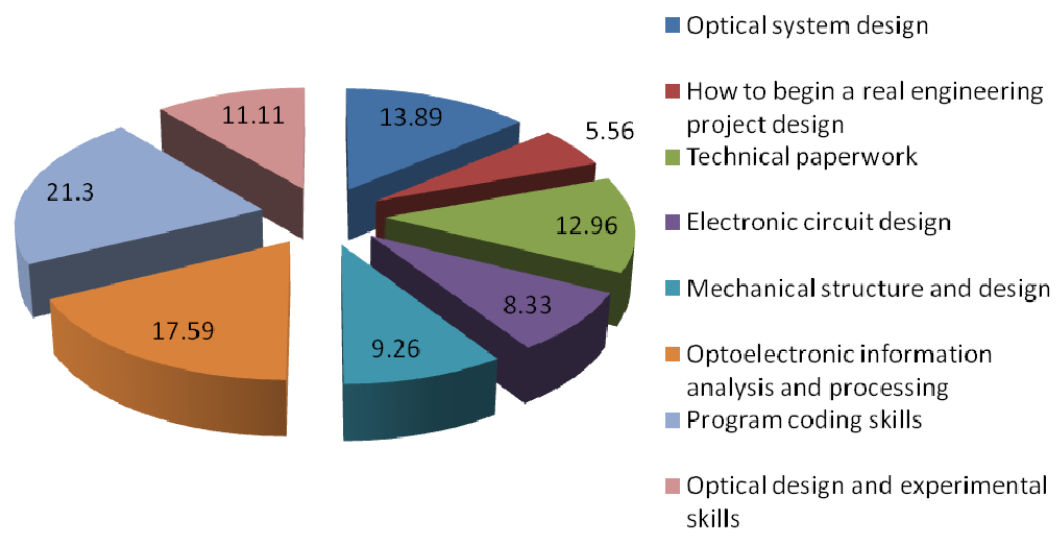

Figure 1. The popularity (\%) of each independent topic according to a recent survey conducted among 55 students.

As the figure indicates, coding skills is the most required knowledge they want to learn, followed by optoelectronic information analysis and processing. The project beginner's guide gets the least vote, which is the most lacking part among the students' skills we found during our past nine years' experience. Anyway, the statistics are just a reference for it is a pre-course survey and it is the same survey which point out that only 8 out of 55 students understand the meaning of PBL. We will conduct another survey after the course, let's wait to see.

\section{DISCUSSION AND FUTURE WORK}

As engineering educators, the engineer in education field whose products are students, we view quality teaching of undergraduates as being on par with other scholarly responsibilities and achievements. There is no absolute right solution to any issue in education because what we are dealing with is young students, each one of them is individual with distinguish personality. Blended learning has its pros and cons. In this paper, we discuss a thought about blending traditional classroom education; project based experimental learning and online lecture model. Hit or miss, we have to keep trying.

\section{ACKNOWLEDGEMENTS}

This work was made possible by a grant from Educational and Teaching Reform Project of Beijing Institute of Technology. 


\section{REFERENCES}

[1] Dhirendra Kumar, Pros and Cons of Online Education, White Papers of NCSU Industry Expansion Solutions, 2015. https://www.ies.ncsu.edu/resources/white-papers/pros-and-cons-of-online-education/.

[2] Ya Zhou, Yao Hu, Liquan Dong, Yuejin Zhao, Yong Song, Qun Hao, "Optoelectronic Instrument Experiments Course: A Trial of Project-based Learning," Proceedings of the 7th International Conference on Computer Science \& Education (ICCSE 2012), Melbourne, Australia, 2012, pp1375-1379.

[3] Susan Ambrose, L. Dee Fink and Daniel Wheeler, "Becoming a Professional Engineering Educator: A New Role for a New Era," Journal of Engineering Education, Special Issue: The Art \& Science of Engineering Education, 94(1), 2005, pp185-194.

[4] Ya Zhou, Yao Hu, Liquan Dong, Yuejin Zhao, Yong Song, Qun Hao, "Several Issues and Possible Solutions in Compulsory Project-based Course", 2014 Frontiers in Education Conference Proceedings (FIE 2014), Madrid, Spain, 2014:1-7.

[5] Yao Hu, Ya Zhou, Liquan Dong, Ming liu, Yuejin Zhao, Qun Hao, "Aptitude Digging Education in Projectbased Course," 2013 Frontiers in Education Conference Proceedings (FIE 2013), Oklahoma City, Oklahoma, USA, 2013, pp41-43.

[6] Online VS Classroom Education, Technical Vocational Schools Guide. http://www.technical-vocationalschools.com/online_classroom_learning.aspx/

[7] Boyd R L. Customer Service in Higher Education: Finding a Middle Ground[J]. The Staff Development Forum. Sdf.ac.uk. 